\title{
Feeding effects of total mixed ration on rumen metabolic profile in Cattle
}

\author{
R Jahan ${ }^{1}$, MR Amin ${ }^{1 *}$, NR Sarker ${ }^{2}$ and MT Kamal ${ }^{1}$
}

${ }^{1}$ Department of Animal Science, Bangladesh Agricultural University, Mymensingh-2202, Bangladesh, ${ }^{2}$ Bangladesh Livestock Research Institute, Savar, Dhaka, Bangladesh

\begin{abstract}
A feeding trial was undertaken to select the best combination of roughage and concentrate based on total mixed ration (TMR), to better rumen environment and determine the feeding effects of TMR on rumen metabolic profile in cattle. The experiment was conducted at Bangladesh Livestock Research Institute (BLRI) for a period of 35 days. A total of 5 types of TMR was prepared on fed basis with different roughage and concentrate ratios as $T_{1}=70: 30, T_{2}=60: 40, T_{3}=50: 50, T_{4}=40: 60$, and $T_{5}=30: 70$. Five cannulated bulls with an average live weight ranging from 200 to $300 \mathrm{~kg}$ and approximately 18 months of age were selected for the experiment. The present study indicated that there was no significant difference in $\mathrm{pH}$ among different treatment groups. Concentration of total volatile fatty acids (TVFAs) was highest in $\mathrm{T}_{2}$ group which was found to be increased up to $12 \mathrm{~h}$ after feeding, then gradually decreased up to $24 \mathrm{~h}$. Concentration of total nitrogen (TN), ammonia nitrogen $\left(\mathrm{NH}_{3}-\mathrm{N}\right)$, non protein nitrogen (NPN) and protein nitrogen (PN) were highest in $\mathrm{T}_{5}$ group. Concentration of total nitrogen (TN), ammonia nitrogen $\left(\mathrm{NH}_{3}-\mathrm{N}\right)$ and protein nitrogen (PN) were gradually decreased up to $12 \mathrm{~h}$ after feeding but then gradually increased trend observed up to $24 \mathrm{~h}$. Concentration of non protein nitrogen (NPN) was found to be decreased gradually from $0 \mathrm{~h}$ up to $24 \mathrm{~h}$ after feeding. The result also indicated that rumen $\mathrm{NH}_{3}-\mathrm{N}$ was positively correlated with TN intake of the animal. It can be concluded from the present study that the TMR provided better rumen environment at different hours of digestion could be used for better rumen fermentation. The best combination of roughage to concentrate ratio (30:70) was in $T_{5}$ group for better $\mathrm{N}$ utilization to achieve maximum performance through proper feeding which might reflect the gross return of cattle production.
\end{abstract}

Key words: feeding effects, total mixed ration, rumen metabolic profile, cattle feed

Bangladesh Animal Husbandry Association. All rights reserved.

Bang. J. Anim. Sci. 2018. 47 (1):35-39

\section{Introduction}

In the context of Bangladesh, feeds and fodder scarcity is the major problem for better livestock production (Tareque and Chowdhury, 2010). Most of the livestock farmers meet their fodder requirements by grazing animals on common lands, fallow or harvested agricultural land. Large farmers also meet fodder requirements through cultivated forage crops. But due to rapid decline of grazing land and farmer's dependency on concentrate feeds, this will not be possible for sustaining such alternative. Regarding this situation, total mixed rations (TMR) can be an alternative solution to support the dairy cows for achieving maximum production by stall feeding without grazing indoor-housed system like dairy producing countries of the world.
TMR enhances feed intake, improves the ecology of the rumen that leads to stimulated microbial activity to digest more feed, increase dry matter intake and milk production (Wachirapakorn et al. 1997) compared to separate feeding which ultimately increases productivity of the cattle. The cost of feed production is rising in the livestock husbandry industry largely due to dietary dependency on raw material. New feeding habits and strategies employing different roughages are clearly necessary to overcome the problem. The TMR has been the subject of great interest from farmers because of its expected benefits in the nutrition, management and production of ruminant animals. The present study was undertaken to compare different ration of TMR based on combination of roughage and concentrate and select the best one for better rumen environment.

*Corresponding author: aminmr64@yahoo.com 


\section{Materials and Methods}

\section{Site of the experiment}

The experiment was conducted at Bangladesh Livestock Research Institute (BLRI), Savar, Dhaka.

\section{Animal selection}

Five cannulated bulls with an average live weight of 200 to $300 \mathrm{~kg}$ and approximately 18 months of age were selected for the experiment.

\section{Dietary Treatments}

During the trial period five cannulated bulls were randomly assigned in replicated 5x5 Latin Square Design (LSD) and were fed with total mixed ration (TMR) diets. Diet combinations of roughage: concentrate was 70:30 $\left(T_{1}\right) ; 60: 40\left(T_{2}\right) ; 50: 50$ $\left(T_{3}\right) ; 40: 60\left(T_{4}\right)$ and 30:70 $\left(T_{5}\right)$. Different types of TMR had been produced with different ratio of roughages (grind soybean straw) and concentrates (Table 1).The total mixed ration (TMR) contained around 16\% CP.

\section{Collection Trial}

During the trial period, daily feed intake and leftover feed were recorded individually. Approximately, $50 \mathrm{ml}$ of rumen fluid were collected using the installed syringe on the $7^{\text {th }}$ day of each experimental period at $0,3,6,12$ and 24 $\mathrm{h}$ after feeding. The $\mathrm{p}^{\mathrm{H}}$ was measured immediately after collection.

\section{Chemical analysis}

Chemical analysis of the collected rumen liquor samples for the estimation of the following parameters were done in the Animal Nutrition Laboratory at BLRI. Rumen $\mathrm{pH}$, Total Volatile Fatty Acids (TVFA), Total nitrogen (TN), Ammonia Nitrogen $\left(\mathrm{NH}_{3}-\mathrm{N}\right)$, Total Solids (TS), Non Protein Nitrogen (NPN), Protein Nitrogen (PN) were studied in the experiment to evaluate the feeding effects of rumen environment in ruminants.

\section{Statistical analysis}

An analysis of variance was done to determine the significant differences in treatment means. Collected data were analyzed statistically by Post Hoc Multiple Comparisons of SPSS 11.5 for Windows (SPSS Inc. 2002). The layout of the experiment was in Latin Square Design (LSD).

Table 1. Composition of total mixed ration (TMR) for different treatment groups

\begin{tabular}{|c|c|c|c|c|c|c|}
\hline \multirow{2}{*}{$\begin{array}{l}\text { Feed type and } \\
\text { nutrients }\end{array}$} & \multirow[t]{2}{*}{ Ingredients $(\mathrm{kg})$} & \multicolumn{5}{|c|}{ Roughage to concentrate ratios in TMR } \\
\hline & & $\mathrm{T}_{1}$ & $T_{2}$ & $T_{3}$ & $\mathrm{~T}_{4}$ & $T_{5}$ \\
\hline \multirow[t]{2}{*}{ Roughage } & Napier-3 silage & 56 & 48 & 40 & 32 & 24 \\
\hline & Milled soybean straw & 14 & 12 & 10 & 8 & 6 \\
\hline \multirow{4}{*}{ Concentrate } & Khesari bran & 3 & 10 & 13 & 23 & 28 \\
\hline & Wheat bran & 6.5 & 10.5 & 19 & 20 & 26 \\
\hline & DCP & 2.5 & 2.5 & 2.5 & 2.5 & 2.5 \\
\hline & Salt & 0.5 & 0.5 & 0.5 & 0.5 & 0.5 \\
\hline \multicolumn{2}{|c|}{ Total fresh amount $(\mathrm{Kg})$} & 100 & 100 & 100 & 100 & 100 \\
\hline \multirow{3}{*}{ Nutrients } & DM (\% Fresh basis) & 53.36 & 54.34 & 59.86 & 61.84 & 64.22 \\
\hline & CP (\% DM basis) & 16.76 & 16.25 & 16.16 & 16.06 & 15.10 \\
\hline & $\mathrm{ME}(\mathrm{MJ} / \mathrm{Kg} \mathrm{DM})$ & 9.45 & 9.81 & 9.55 & 9.70 & 9.72 \\
\hline
\end{tabular}

$\mathrm{T}_{1}=70: 30$ (Roughage: Concentrate), $\mathrm{T}_{2}=60: 40$ (Roughage: Concentrate), $\mathrm{T}_{3}=50: 50$ (Roughage: Concentrate), $\mathrm{T}_{4}=40: 60$ (Roughage: Concentrate), $\mathrm{T}_{5}=30: 70$ (Roughage: Concentrate). 


\section{Results and Discussion}

\section{Rumen fermentation parameters}

\section{Rumen pH}

The Rumen $\mathrm{pH}$ of different treatment groups were shown in Fig 1 . All the treatment $\mathrm{pH}$ were found decreasing gradually from 0 hour to 6 hour after feeding, then increased at 12 hour and again decreased at 24 hour (Fig.1). This also indicated that there was no sequential change in $\mathrm{p}^{\mathrm{H}}$ in different treatment groups.

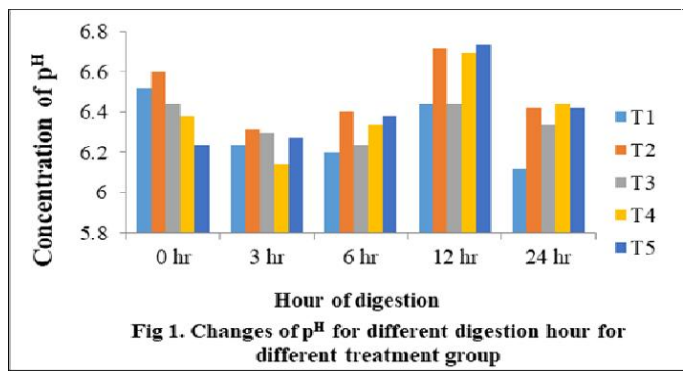

The results of the present study corrugated with the observation of Williams and Christian, (1959). They reported no corresponding changes in rumen $\mathrm{pH}$ value in different treatment groups.

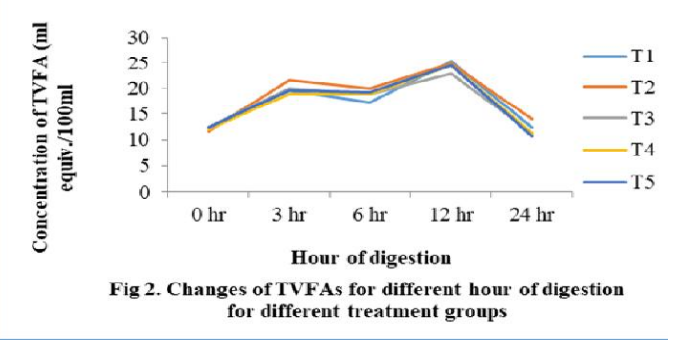

\section{Total volatile fatty acids}

The changes of TVFA concentrations in different treatment groups were found to be increased up to $12 \mathrm{~h}$ after feeding but gradually decreased its concentration up to $24 \mathrm{~h}$ (Fig. 2). The TVFA at 0 hour and at 24 hour post feeding for any of the treatment groups were almost similar. Among the treatment groups, the concentration of TVFAs in $T_{2}$ group was tended to be higher irrespective of sampling hours (Fig.2). Reid et al., (1957), conducted experiments at Massey University sequentially reported that with pasture fed to cows indoor or grazed have shown that comparatively large changes occur in rumen TVFA value with time after feeding. The concentration of TVFA was increased to a peak at three to six hours after the start of feeding. Further it showed that TVFAs production was highest at 12 hour post feeding and the TVFA production from o hour to 3 and 6 hours was increasing.

\section{Total nitrogen (TN)}

The changes of TN concentrations in different treatment groups were found decreasing gradually up to $12 \mathrm{~h}$ after feeding, but then increased gradually up to $24 \mathrm{~h}$ (Fig. 3). Among the treatment group the concentration of TN in $\mathrm{T}_{5}$ group was highest irrespective of sampling hours (Fig. 3). Bourg, (2012) also reported that protein of low nitrogen solubility had more value for ruminants than highly soluble nitrogen source. The nature of dietary protein affects the ruminal TN.

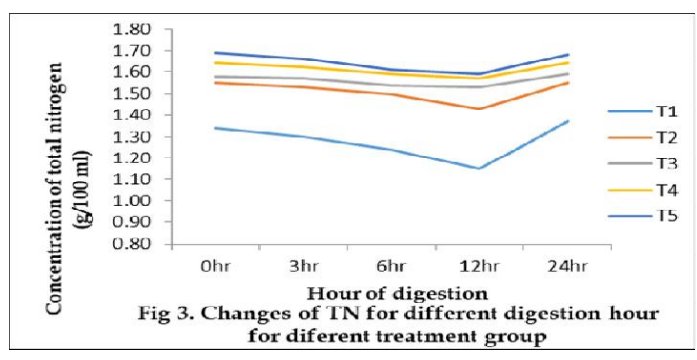

\section{Ammonia nitrogen $\left(\mathrm{NH}_{3}-\mathrm{N}\right)$}

The changes of $\mathrm{NH}_{3}-\mathrm{N}$ concentrations in different treatment groups were found decreasing gradually towards $12 \mathrm{~h}$ after feeding but then again increased up to $24 \mathrm{~h}$ (Fig.4). The $\mathrm{NH}_{3}-\mathrm{N}$ at 0 hour and at 24 hour after feeding for any of the treatment groups was almost the similar. The concentration of $\mathrm{NH}_{3}-\mathrm{N}$ in $\mathrm{T}_{5}$ was tended to be higher irrespective of sampling hours (Fig.4).

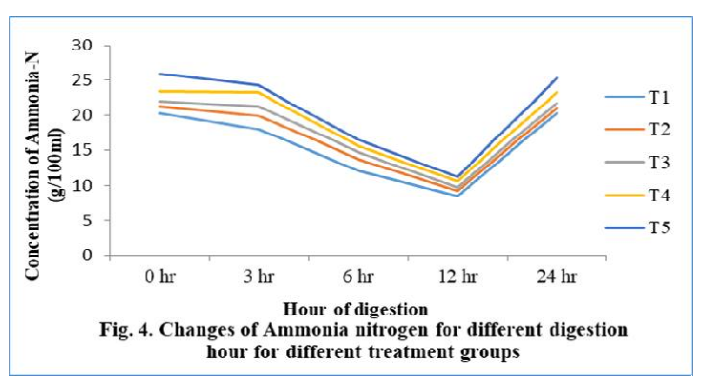

Spires and Clark (1979) observed that protein with high solubility in the rumen produced more ammonia and subsequently less efficiently 
utilized. According to Carvalho et al., (1997), the reduction in ruminal $\mathrm{NH}_{3}-\mathrm{N}$ concentration can be explained by the increase in energy availability in the rumen, allowing higher use of ammonia for microbial growth, with consequent reduction in ammonia loss due to synchronization in the carbohydrates and protein degradation.

\section{Total solids (TS)}

The changes of TS concentrations in different treatment groups were found to be increased gradually from 0 hour up to $24 \mathrm{~h}$ after feeding. The concentration of TS in $\mathrm{T}_{3}$ was tended to be higher irrespective of sampling hours (Fig. 5)

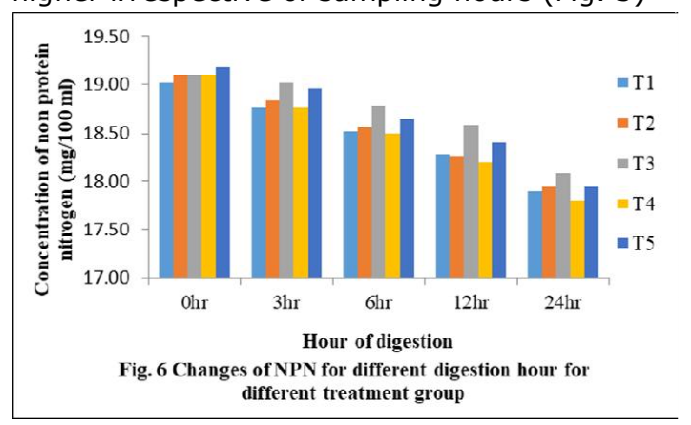

\section{Non protein nitrogen (NPN)}

The changes of NPN concentrations in different treatment groups were found to be decreased gradually up to $24 \mathrm{~h}$ after feeding. The concentration of NPN in $T_{5}$ was tended to be higher irrespective of sampling hours (Fig. 6).

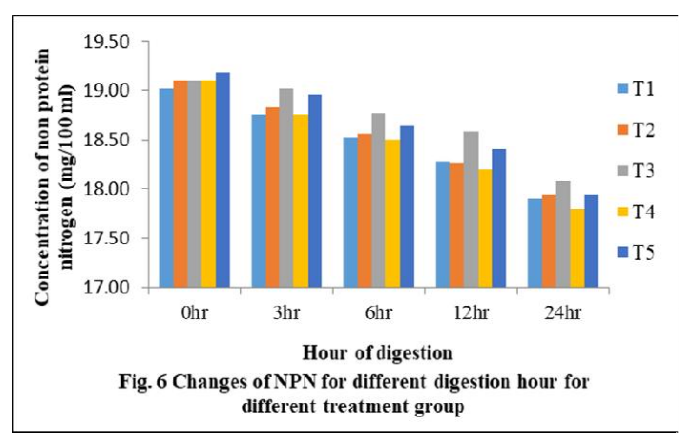

\section{Protein nitrogen (PN)}

The changes of PN concentrations in different treatment groups were found to be decreased up to $12 \mathrm{~h}$ after feeding but increased its concentration up to $24 \mathrm{~h}$ (fig. 7). The PN at 0 hour and at 24 hour after feeding for any of the treatment groups were almost similar. The concentration of $\mathrm{PN}$ in $\mathrm{T}_{5}$ was tended to be higher irrespective of sampling hours (fig 7)

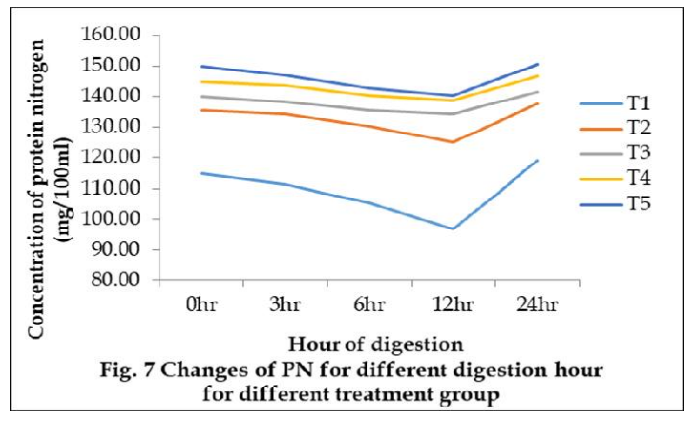

Conflicts of interest

We, the affiliated authors whose names are mentioned in the manuscript, hereby, clearly certify that, we have no affiliations with or involvement in any organization or entity with any financial interest or non-financial interests in the subject matter or materials discussed in this manuscript.

\section{Conclusion}

Total mixed rations (TMR) can help to achieve maximum performance and can be the most adopted method for feeding high producing animals in almost all over the world. The best combination of roughage to concentrate ratio was in $T_{5}$ group for better $\mathrm{N}$ utilization to achieve maximum performance through proper feeding. It can be concluded from the findings of the present study that using a combination of the proper amount of roughage and concentrates in a TMR ensure better rumen environment for fermentation and TMR can very well replace the other high nutritive and expensive roughage sources without adversely affecting growth and milk production in indigenous dairy cow.

\section{References}

AOAC (1995). Officials Methods of Analysis. (16 $6^{\text {th }}$ edition), Association of Official Analytical Chemist. Washington D.C. USA.

BBS (2004).Bangladesh Bureau of Statistics. Statistical Yearbook.

Bourg MJ (2012). Influences of dietary nitrogen metabolism in the rumen. Dairy Science 47:1237-1242.

Carvalho AS (1997). Ammonia nitrogen determination in plant material. Netherlands Journal of Agriculture 22:3-5.

Reid RL, JP Hogan and PK Briggs (1957).The effect of diet on individual volatile fatty acids in the rumen of sheep, with particular reference to the effect of low rumen $\mathrm{pH}$ and adaptation on 
Jahan et al. (2018) Bang. J. Anim. Sci. 47 (1):35-39

high starch diets. Australian Journal Agricultural Research 8:691-710.

Spires SP and DK Clark (1979). Nitrogen metabolism and supply of amino acids. Journal of Dairy Science 92:5620-5633.

Tareque AMM and SMZH Chowdhury (2010). Agricultural Research Priority: Vision-2030 and Beyond.Sub-sector: Livestock (Dhaka: Bangladesh Agricultural Research Council). Available online at: http://www. barc.gov.bd/documents/Final-Prof.Tareque.pdf (accessed 30 December 2012).
Wachirapakorn C, T Puramongkol and V Seepuang (1997). Total mixed ration (TMR) or complete ration (CR) for dairy cows. Journal of Dairy Cows 5:53

Williams VJ and KR Christian (1959). Concentrations of end products and morphological types of rumen bacteria in silage fed sheep. New Zealand Journal of Agricultural Research 2:387-393. 